\title{
Pengaruh Motivasi, Biaya Pendidikan Dan Lama Masa Studi Pada Minat Mahasiswa Mengikuti PPAk
}

\author{
Ni Luh Ira Apri Widiyani ${ }^{1}$ \\ Fakultas Ekonomi dan Bisnis \\ Universitas Udayana, Indonesia. \\ Email: ira.apree@yahoo.co.id
}

\author{
I Dewa Nyoman Badera ${ }^{2}$ \\ Fakultas Ekonomi dan Bisnis \\ Universitas Udayana, Indonesia.
}

\begin{abstract}
ABSTRAK
Penelitian ini dilakukan di Fakultas Ekonomi dan Bisnis Universitas Udayana. Sampel dalam penelitian ini adalah mahasiswa akuntansi angkatan 2016 program non regular. Banyaknya sampel yang digunakan adalah 60 responden yang ditentukan menggunakan metode non probability sampling dengan teknik purposive sampling. Hasil penelitian menemukan bahwa motivasi kualitas, motivasi sosial, motivasi ekonomi berpengaruh positif pada minat mahasiswa mengikuti PPAk. Hal ini berarti semakin baik motivasi maka akan meningkatkan minat mahasiswa mengikuti PPAk. Biaya pendidikan dan lama masa studi berpengaruh positif pada minat mahasiswa mengikuti PPAk. Hal ini berarti semakin sesuai biaya pendidikan dan lama masa studi maka akan meningkatkan minatmahasiswa mengikuti PPAk.

Kata Kunci: $\quad$ Motivasi Biaya Pendidikan; Lama Masa Studi; Minat Mahasiswa Mengikuti PPAk.

\section{Effect of Motivation, Education Costs and Length of Study Period on Student Interest in Participating in PPAK}

\begin{abstract}
This research was conducted at the Faculty of Economics and Business, Udayana University. The sample in this study is the 2016 non-regular program accounting students. The number of samples used was 60 respondents who were determined using a non probability sampling method with a purposive sampling technique.. The results of the study found that quality motivation, social motivation, economic motivation had a positive effect on students' interest in participating in PPAk. This means that the better the motivation will increase the interest of students in participating in PPAk. The cost of education and the length of the study period have a positive effect on students' interest in joining PPAk. This means that the more appropriate the cost of education and the length of the study period will increase students' interest in joining PPAk.
\end{abstract}

Keywords: Motivation; Tuition Fee; Length Of Study Period; Interest In Students Participating in PPAk

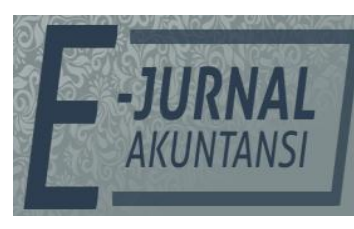

E-JA

e-Jurnal Akuntansi e-ISSN 2302-8556

Vol.298 No. 1

Denpasar, Oktober

2019

Hal. 188-204

Artikel masuk:

05 Juli 2019

Tanggal diterima:

30 September 2019 


\section{PENDAHULUAN}

Di era globalisasi saat ini, dunia pendidikan terus mengalami perubahan dan kemajuan yang sangat pesat dibandingkan dengan era sebelumnya. Dengan adanya perubahan dan perkembangan yang pesat, peningkatan kualitas hidup menjadi keinginan orang-orang saat ini. Namun dengan adanya persaingan yang ketat, diperlukan seseorang dengan latarbelakang pendidikan yang berkualitas dan memiliki kemampuan serta pengalaman kerja agar dapat bersaing dalam dunia kerja. Hal ini yang kemudian turut menjadi pertimbangan bagi para mahasiswa baru dalam memilih jurusan yang nantinya memiliki peluang tinggi untuk mendapatkan kerja di masa yang akan datang.

Sebagian besar mahasiswa jurusan akuntansi menganggap profesi akuntan tidak terlepas dari lingkungan bisnis yang terjadi di negeri ini, karena profesi akuntan menjadi salah satu pelaku aktif di dunia bisnis dan ekonomi. Pendidikan Profesi Akuntansi adalah pendidikan lanjutan pada pendidikan tinggi untuk mendapatkan gelar Profesi Akuntan. Lulusan Pendidikan Profesi Akuntansi berhak menyandang sebutan gelar profesi akuntan yang disingkat Ak.

Pendidikan Profesi Akuntanis (PPAk) penting bagi mahasiswa jurusan akuntansi sebab Pendidikan Profesi Akuntansi dapat memberikan kontribusi untuk menjadi seorang akuntan yang profesional (Nazir, 2008: p. 11). Mengingat pentingnya PPAk bagi mahasiswa akuntansi maka diperlukan motivasi dari dalam diri mahasiswa terhadap minat untuk mengikuti PPAk yang diharapkan dapat mencapai tujuan yang diinginkanmahasiswa tersebut.

Berdasarkan surat keputusan (SK) Mendiknas No. 179/U/2001 gelar akuntan hanya dapat disandang melalui PPAk di perguruan tinggi dan mendapat izin penyelenggaraan dari Direktorat Jendral Pendidikan Tinggi. Standar yang khusus membahas tentang mahasiswa akuntansi adalahStandar yang dikeluarkan oleh bagian pendidikan dari International Federation of Accountants (IFAC) yaitu International Accounting Education Standards Boards (IAESB) yang menghasilkan sebuahStandar yang dinamakan International Education Standard (IES). Standar ini merupakan isi dan rencana impelementasi panduan global untuk membentuk akuntan profesional maupun akuntan yang lainnya dan telah dilakukan oleh kalangan profesi dan perguruan tinggi (Nazir, 2008: . 11).

Masyarakat Ekonomi Asean (MEA) membuat Akuntan asing dapat dengan mudah masuk dan berkarir di Indonesia. Pemerintah mengeluarkan UU.No. 5 Tahun 2011 tentang Akuntan Publik dimana untuk melindungi akuntan dalam negeri dari kemungkinan banyaknya akuntan asing yang masuk juga untuk meningkatkan profesional akuntan.

Tabel 1. JumlahAnggotaAsosiasiAkuntan

\begin{tabular}{ccc}
\hline Negara & Asosiasi & Total \\
\hline Indonesia & IAI & 24.587 \\
Malaysia & MIA & 31.815 \\
Filipina & PICPA & 18.214 \\
Thailand & FAP & 62.739 \\
Singapura & ICPAS & 28.891 \\
\hline
\end{tabular}

Sumber: IkatanAkuntansi Indonesia, 2017 
Tabel 1 menyajikan bahwa Thailand memiliki jumlah anggota asosiasi akuntan yang tertinggi yaitu sebanyak 62.739 orang. Berbanding terbalik dengan Indonesia yang memiliki jumlah anggota asosiasi akuntan yang rendahya itu sebanyak 24.587 orang. Hal ini menunjukan bahwa di Indonesia minat untuk menjadi akuntan masih rendah. Minimnya jumlah akuntan publik saat ini, merupakan salah satu yang dihadapi oleh profesi akuntan publik. Ketidak mantapan peran dan posisi profesi akuntan publik bisa jadi merupakan salah satu penyebabnya (Diah, 2012).

Fakultas Ekonomi dan Bisnis Universitas Udayana adalah salah satu universitas yang menyelenggarakan program PPAk di Provinsi Bali dengan izin penyelenggaraan yang dikeluarkan oleh Direktorat Jendral Pendidikan Tinggi No. 3827/D/T/2003, tertanggal 20 Nopember 2003. Pendidikan Profesi Akuntansi Fakultas Ekonomi dan Bisnis Universitas Udayana beroperasi sejak tanggal 1 April 2004 hingga sekarang. Adapun profil perkembangan jumlah mahasiswa di PPAk Fakultas Ekonomi dan Bisnis Universitas Udayana dari angkatan XXII-XXIX (Periode Tahun 2015-2018) dapat disimak pada Tabel 2 berikut ini.

Tabel 2. Perkembangan Jumlah Mahasiswa Pendidikan Profesi Akuntansi Fakultas Ekonomi dan Bisnis Universitas Udayana Tahun 2015-2018

\begin{tabular}{cccc} 
Tahun Akademik & Angkatan & $\begin{array}{c}\text { Jumlah Mahasiswa } \\
\text { Mendaftar }\end{array}$ & $\begin{array}{c}\text { Jumlah Mahasiswa } \\
\text { Diterima }\end{array}$ \\
\hline \multirow{2}{*}{2015} & XXII & 26 & 24 \\
\multirow{2}{*}{2016} & XXIII & 28 & 26 \\
& XXIV & 11 & 9 \\
2017 & XXV & 18 & 18 \\
& XXVI & 15 & 14 \\
2018 & XXVII & 19 & 16 \\
& XXVIII & 20 & 19 \\
& XXIX & 25 & 25 \\
\hline
\end{tabular}

Sumber: PPAK FEB Unud, 2018

Data yang ditampilkan pada Tabel 2, dapat dilihat bahwa pada tahun akademik 2015-2018 angkatan XXII-XXIX mengalami naik turun atau fluktuatif jumlah mahasiswa mendaftar dan jumlah mahasiswa diterima. Hal tersebut menunjukkan bahwa minat mahasiswa akuntansi khususnya dari Universitas Udayana terhadap profesi akuntan relatif masih rendah.

Rendahnya minat untuk mengikuti Pendidkan Profesi Akuntansi disebabkan dengan dikeluarkannya Peraturan Menteri Keuangan Nomor 216/PMK.01/2017 tentang Akuntan beregister Negara. Dimana dengan dikeluarkannya peraturan tersebut, lulusan PPAk tidak langsung mendapat ijazah serta mendapat gelar Akuntan beregister Negara. Untuk dapat memperoleh gelar Akuntan beregister Negara, seseorang harus mengikuti ujian sertifikasi profesi akuntansi terlebih dahulu dan memiliki bukti lulus ujian sertifikasi profesi akuntansi yang diselenggarakan oleh Asosiasi Profesi Bidang Akuntansi, menjadi anggota Asosiasi Profesi Bidang Akuntansi, berpengalaman praktik di bidang akuntansi paling sedikit tiga tahun, dan memiliki Nomor Pokok Wajib Pajak. PMK ini dibentuk bertujuan untuk mewujudkan terciptanya akuntan yang profesional dan mempunyai daya saing di tingkat global. 
Adapunfaktor-faktor yang memengaruhi adanya motivasi kualitas, motivasi sosial, motivasi ekonomi, biaya pendidikan dan lama masa studi berperan dalam menentukan minat mahasiswa mengikuti Pendidikan Profesi Akuntansi.

Motivasi kualitas merupakan dorongan yang timbul dari dalam diri seseorang untuk memiliki dan meningkatkan kualitas atau kemampuannya dalam melaksanakan tugasnya dengan baik dan benar Widyastuti \& Juliana (2004). Dalam hal ini berkaitannya dengan dorongan untuk meningkatkan pengetahuan dalam hal akuntansi, perpajakan, audit atau keuangan, meningkatkan kemampuan interpersonal, kemampuan manajerial serta kemampuan lainnya yang berhubungan dengan kualitas individu. Penelitian yang dilakukan oleh (Aryani \& Erawati , 2016) dan (Dyastasari \& Yadnyana, 2016) menunjukkan bahwa motivasi kualitas berpengaruh positif pada minat mahasiswa mengikuti Pendidikan Profesi Akuntansi. Berbeda dengan hasil penelitian yang dilakukan oleh (Andoko \& Sukhemi, 2015) motivasi kualitas tidak berpengaruh pada minat mahasiswa mengikuti Pendidikan Profesi Akuntansi.

Motivasi sosial merupakan motivasi yang mendasari aktivitas yang dilakukan individu dalam reaksinya terhadap orang lain, jika ia dalam membuat pilihan memperhitungkan akibatnya bagi orang lain (Martameh, 2012). Membutuhkan kondisi dan situasi lingkungan yang baik saat bekerja sebagai akuntan. Seorang akuntan lebih dihargai dalam bekerja serta mendapatkan tempat yang baik dalam masyarakat memerlukan pengaruh nilai sosial. Nilainilai sosial ditunjukkan sebagai faktor yang mencerminkan kemampuan seseorang pada masyarakatnya, dengan kata lain nilai-nilai sosial adalah nilai seseorang dari sudut pandang orang lain di lingkungannya (Widyasari, 2010). Penelitian yang dilakukan oleh Nurhayati (2012) dan Kusumo \& Ahyani (2015)menunjukan bahwa motivasi sosial berpengaruh positif pada minat mahasiswa mengikuti Pendidikan Profesi Akuntansi. Sejalan dengan hasil penelitian yang dilakukan oleh Indrawati (2009) menyatakan bahwa motivasi sosial berpengaruh positif terhadap minat mahasiswa mengikuti Pendidikan Profesi Akuntansi. Namun penelitian ini tidak sejalan dengan penelitian yang dilakukan oleh Ayuningtyas dan Prihatini (2012) dan Vesperalis dan Muliartha (2017) yang menunjukkan bahwa motivasi sosial berpengaruh negatif pada minat mahasiswa mengikuti pendidikan profesi akuntansi.

Motivasi ekonomi dapat diartikan sebagai suatu dorongan yang timbul dari dalam diri seseorang untuk meningkatkan kemampuan pribadinya dalam rangka mencapai penghargaan finansial dan kemampuan ekonominya. Motivasi ini erat kaitannya dengan keinginan seseorang dalam hal memenuhi materiil, seperti memperoleh gaji yang besar, mendapatkan tunjangan yang banyak, memperoleh fasilitas seperti mobil, rumah, dan telepon, memperoleh bonus setiap akhir tahun, dan dorongan lainnya. Penelitian yang dilakukan oleh Kurniawan(2017) dan Aryani \& Erawati (2016) yang menyatakan bahwa motivasi ekonomi berpengaruh positif pada minat mahasiswa mengikuti Pendidikan Profesi Akuntansi. Berbeda dengan penelitian yang dilakukan oleh Diah (2012) yang menunjukkan bahwa motivasi ekonomi berpengaruh negatif pada minat mahasiswa mengikuti Pendidikan Profesi Akuntansi. 
Biaya pendidikan yaitu semua jenis pengeluaran yang dikeluarkan untuk menyelenggarakan pendidikan (Wijaya, 2010). Pengeluaran ini dilakukan agar memperoleh manfaat yang dirasakan pada masa mendatang. Penelitian Kurniawan (2017), Pita \& Sasongko (2016) serta Sapitri \& Yaya (2015) menunjukkan biaya pendidikan berpengaruh positif pada minat mahasiswa mengikuti PPAk. Sedangkan penelitian yang dilakukan oleh Aryani \& Erawati (2016) menemukan hasil yang berbeda yaitu biaya pendidikan tidak berpengaruh pada minat mahasiswa mengikuti Pendidikan Profesi Akuntansi.

Lama masa studi adalah masa studi terjadwal yang harus ditempuh oleh mahasiswa sesuai dengan rentang waktu yang dipersyaratkan. Mereka menganggap kurun waktu kuliah selama menempuh S1 akuntansi selama empat tahun ditambah dengan waktu mengikuti PPAk selama 1 sampai 1,5 tahun hingga akhirnya bekerja, terlalu lama (Puspitarini \& Kusumawati, 2011). Permasalahan ini membuat banyak lulusan yang pada akhirnya memilih untuk bekerja terlebih dahulu daripada mengikuti Pendidikan Profesi Akuntansi. Permasalahan tentang masa studi yang dianggap lama atau tidak merupakan persepsi mahasiswa dan bersifat relatif tergantung dari penilaian masingmasing. Penelitian yang dilakukan (Yuneriya, et al., 2013) yang menyatakan lama masa studi berpengaruh positif pada minat mahasiswa mengikuti Pendidikan Profesi Akuntansi. Namun penelitian yang dilakukan oleh (Pita \& Sasongko, 2016) lama masa studi berpengaruh negatif pada minat mahasiswa mengikuti Pendidikan Profesi Akuntansi.

Teori motivasi maslow mengaitkan kebutuhan pemenuhan diri untuk mempergunakan potensi ekspresi diri dan melakukan apa yang sesuai dengan dirinya. Peran dari motivasi maslow ini agar kebutuhan pemenuhan seseorang untuk memiliki dan meningkatkan kualitas dan kemampuan di bidang yang ditekuninya.

Motivasi kualitas adalah motivasi seseorang untuk memiliki dan meningkatkan kualitas diri dan kemampuannya dalam bidang pekerjaan yang menghasilkan kinerja yang baik dan benar. Dalam profesi akuntansi elemen kualitas dan kompensansi merupakan hal yang sangat diperhatikan dalam profesi akuntansi, khususnya profesi akuntan publik, bahkan elemen ini dimasukkan kedalam standar audit (Rahardian, 2008). Taraf peningkatan kualitas serta kemampuan dapat diukur melalui seberapa kuat minat yang dimiliki oleh seseorang.

Guna meningkatkan kualitas diri dari mahasiswa diperlukan motivasi yang dapat menggerakan jiwa dan jasmani dengan cara menempuh Pendidikan Profesi Akuntansi. Penelitian yang dilakukan oleh (Aryani \&Erawati, 2016) dan (Dyastasari \& Yadnyana, 2016) menunjukkan bahwa motivasi kualitas berpengaruh positif pada minat mahasiswa mengikuti Pendidikan Profesi Akuntansi. Berdasarkan uraian tersebut dapat dijelaskan bahwa, semakin baik motivasi kualitas yang dimiliki maka akan meningkatkan minat mahasiswa mengikuti pendidikan profesi akuntansi. Berdasarkan alasan tersebut, hipotesis yang dapat dikembangkan adalah:

$\mathrm{H}_{1}$ : Motivasi kualitas berpengaruh positif pada minat mahasiswa mengikuti pendidikan profesi akuntansi 
Teori motivasi maslow mengaitkan kebutuhan akan status atau kedudukan, kehormatan diri, reputasi dan prestasi. Peran dari motivasi maslow ini agar seseorang dalam melakukan perbuatan dengan tujuan bernilai sosial, memperoleh pengakuan maupun penghargaan dari lingkungan dimana seseorang berada. Dengan mendapat sebutan akuntan, maka muncul kepuasan dalam diri seseorang karena kemampuan yang dimiliki atau prestasi yang diraih mendapat apresiasi oleh orang lain dan lingkungan sekitarnya.

Motivasi sosial merupakan suatu dorongan yang timbul dalam diri seseorang yang melatarbelakangi orang tersebut untuk mendapatkan penghargaan maupun pengakuan dari lingkungan sekitar terhadap pencapaian yang telah dilakukan. Hasil penelitian yang dilakukan oleh Kusumo \& Ahyani (2015) dan Dyastasari \& Yadnyana (2016) menunjukan bahwa motivasi sosial berpengaruh positif pada minat mahasiswa mengikuti Pendidikan Profesi Akuntansi. Sejalan dengan hasil penelitian yang dilakukan oleh (Indrawati, 2009) dan (Nurhayati, 2012)menyatakan bahwa motivasi sosial berpengaruh positif terhadap minat mahasiswa mengikuti Pendidikan Profesi Akuntansi. Namun penelitian ini tidak sejalan dengan penelitian yang dilakukan oleh Ayuningtyas \& Prihatini (2012) dan Vesperalis\& Muliartha (2017) yang menunjukkan bahwa motivasi sosial berpengaruh negatif pada minat mahasiswa mengikuti pendidikan profesi akuntansi. Berdasarkan uraian tersebut dapat dijelaskan bahwa, semakin baik motivasi sosial yang dimiliki maka akan meningkatkan minat mahasiswa mengikuti pendidikan profesi akuntansi. Berdasarkan alasan tersebut, hipotesis yang dapat dikembangkan adalah:

$\mathrm{H}_{2}$ : Motivasi sosial berpengaruh positif pada minat mahasiswa mengikuti pendidikan profesi akuntansi

Teori motivasi maslow merupakan sebuah teori yang menjelaskan bahwa setiap individu mempunyai beraneka ragam kebutuhan yang dapat memengaruhi perilaku mereka(Lubis, 2014: p. 85). Dampak dari implementasi kebijakan terkait dengan Pendidikan Profesi Akuntansi menunjukkan bahwa pendidikan dapat dipengaruhi oleh beberapa faktor, salah satunya adalah faktor ekonomi (Paisey \& Paisey, 2006). Motivasi ekonomi timbul karena tuntutan untuk memenuhi kebutuhan fisiologis, kebutuhan akan keamanan, kebutuhan sosial, kebutuhan akan penghargaan, dan kebutuhan akan aktualisasi diri.

Motivasi ekonomi dinilai dari seberapa besar dorongan meningkatkan penghargaan ekonomi baik berupa penghargaan langsung seperti pembayaran gaji pokok, atau upah dasar, overtime/gaji dari lembur, pembayaran untuk hari libur, dan berbagai bentuk bonus berdasarkan kinerja lainnya. Sedangkan penghargaan tidak langsung meliputi asuransi pembayaran liburan, tunjangan biaya sakit, program pensiun dan berbagai manfaat lainnya.

Hasil penelitian yang dilakukan oleh Salistera \& Kusumastuti (2013), (Perkasa \& Sudarma (2014) dan (Kurniawan, 2017) yang menyatakan bahwa motivasi ekonomi berpengaruh positif pada minat mahasiswa mengikuti Pendidikan Profesi Akuntansi. Berbeda dengan penelitian yang dilakukan oleh (Diah, 2012) yang menunjukkan bahwa motivasi ekonomi berpengaruh negatif pada minat mahasiswa mengikuti pendidikan profesi akuntansi. Berdasarkan uraian tersebut dapat dijelaskan bahwa, semakin baik motivasi ekonomi yang dimiliki maka akan meningkatkan minat mahasiswa mengikuti pendidikan 
profesi akuntansi. Berdasarkan alasan tersebut, hipotesis yang dapat dikembangkan adalah:

$\mathrm{H}_{3:}$ Motivasi ekonomi berpengaruh positif pada minat mahasiswa mengikuti pendidikan profesi akuntansi

Teori motivasi maslow merupakan sebuah teori yang berkaitan dengan hubungan kebutuhan pemenuhan diri untuk mempergunakan kemampuan dan potensi diri dalam mencapai suatu tujuan. Peran dari motivasi maslow ini agar biaya pendidikan yang dikeluarkan oleh mahasiswa sesuai untuk keperluan selama menempuh pendidikan dari awal sampai berakhirnya pendidikan. Dengan adanya biaya pendidikan yang sesuai maka akan meningkatkan minat mahasiswa mengikuti pendidikan profesi akuntansi.

Biaya pendidikan tidak hanya dinilai dari sisi mahal tetapi dapat pula dilihat dari sisi bagaimana kemampuan mempersiapkan serta merasakan biaya yang akan dikeluarkan dihubungkan dengan kelayakan, kemudahan, dan kepatutan dalam mengakses perguruan tinggi tertentu. Sehingga dapat dikatakan bahwa Pendidikan Profesi Akuntansi tidak akan berjalan apabila tidak didukung oleh biaya pendidikan.

Penelitian yang dilakukan oleh (Kurniawan, 2017) dan Sapitri \& Yaya (2015) menunjukkan biaya pendidikan berpengaruh positif pada minat mahasiswa mengikuti Pendidikan Profesi Akuntansi. Berdasarkan uraian tersebut dapat dijelaskan bahwa, semakin sesuai biaya pendidikan maka akan meningkatkan minat mahasiswa mengikuti pendidikan profesi akuntansi. Berdasarkan alasan tersebut, hipotesis yang dapat dikembangkan adalah:

$\mathrm{H}_{4}$ : Biaya pendidikan berpengaruh positif pada minat mahasiswa mengikuti pendidikan profesi akuntansi

Teori motivasi maslow menjelaskan bahwa setiap individu mempunyai beraneka ragam kebutuhan yang berbeda-beda. Peran dari motivasi maslow ini ketika mahasiswa menempuh pendidikan untuk mendapatkan gelar ini merupakan kebutuhan mahasiswa yang diinginkan.

Lama masa studi adalah masa proses dalam menempuh pendidikan yang telah dijadwalkan oleh pihak penyelenggara pendidikan. Mahasiswa harus menempuh pendidikan sesuai dengan tenggang waktu yang telah dipersyaratkan oleh pihak penyelenggara.

Sebagian besar lulusan sarjana ekonomi banyak yang memilih untuk segera bekerja setelah mereka lulus karena adanya desakan ekonomi atau karier. Mereka menganggap kurun waktu kuliah selama menempuh S1 Akuntansi selama empat tahun ditambah dengan waktu mengikuti PPAk selama 1 sampai 1,5 tahun hingga akhirnya bekerja, terlalu lama. Permasalahan ini membuat banyak lulusan yang pada akhirnya memilih untuk bekerja terlebih dahulu daripada mengikuti Pendidikan Profesi Akuntansi.

Namun tidak sedikit juga mahasiswa yang menganggap rentan waktu yang dibutuhkan untuk mengikuti PPAk tersebut tidak terlampau lama, karenahanya 1 tahunsampai 1,5 tahun. Permasalahan tentang masa studi yang dianggap lama atau tidak merupakan persepsi mahasiswa dan bersifat relatif tergantung dari penilaian masing-masing. Hasil penelitian yang dilakukan oleh (Yuneriya et al. 2013) yang menyatakan masa studi berpengaruh positif terhadap minat mahasiswa mengikuti pendidikan profesi akuntansi. Namun penelitian 
yang dilakukan oleh Pita \& Sasongko (2016) lama masa studi berpengaruh negatif pada minat mahasiswa mengikuti Pendidikan Profesi Akuntansi. Berdasarkan uraian tersebut dapat dijelaskan bahwa, semakin sesuai lama masa studi maka akan meningkatkan minat mahasiswa mengikuti pendidikan profesi akuntansi. Berdasarkan alasan tersebut, hipotesis yang dapat dikembangkan adalah:

$\mathrm{H}_{5}$ : Lama masa studi berpengaruh positif pada minat mahasiswa mengikuti pendidikan profesi akuntansi

\section{METODE PENELITIAN}

Penelitian ini dilakukan di Fakultas Ekonomi dan Bisnis Universitas Udayana yang beralamat di Jln. P.B. Sudirman, Denpasar. Alasan di pilihnya Universitas Udayana sebagai lokasi penelitian karena satu-satunya perguruan tinggi yang menyelenggarakan program Pendidikan Profesi Akuntansi di wilayah Bali.

Populasi dalam penelitian adalah seluruh mahasiswa jurusan akuntansi program non regular Fakultas Ekonomi dan Bisnis Universitas Udayana angkatan 2016 yakni sejumlah 134 mahasiswa. Teknik yang digunakan dalam menentukan sampel pada penelitian ini adalah nonprobability sampling dan teknik samplingnya adalah purposive sampling. Agar jumlah sampel yang diambil dari populasi yang digunakan betul-betul representatif, maka untuk menetapkan jumlah sampel dihitung dengan menggunakan rumus Slovin yang menggunakan nilai kritis sebesar 0,10.

Rumus: $\frac{\mathrm{N}}{1+\mathrm{N}\left(\mathrm{e}^{2}\right)}=\frac{134}{1+134\left(0.10^{2}\right)}=57,26$

Keterangan:

$\mathrm{N}=$ Jumlah populasi

$\mathrm{e}=$ Batas ketelitian yang digunakan

Berdasarkan perhitungan di atas maka jumlah sampel dalam penelitian ini adalah sebanyak 57,26 yang kemudian dibulatkan menjadi 60. Dengan demikian jumlah sampel dalam penelitian ini adalah minimal 60 responden.

Teknik analisis data yang digunakan dalam penelitian ini adalah analisis regresi linier berganda. Analisis ini digunakan untuk mengetahui ketergantungan antara satu variabel dependen dengan satu variabel independen atau tanpa variabel moderator, serta untuk mengetahui ketergantungan satu variabel dependen dengan variabel-variabel independen. Model persamaan regresi yang digunakan dalam penelitian ini diasumsikan linier dan diuji dengan tingkat signifikansi $\alpha=5 \%$.

$Y=\alpha+\beta_{1} X_{1}+\beta_{2} X_{2}+\beta_{3} X_{3}+\beta_{4} X_{4}+\beta_{5} X_{5}+\varepsilon$

Keterangan:

a

: Konstanta

$X_{1}$

$X_{2}$

$\mathrm{X}_{3}$

$X_{4}$

$X_{5}$

$\mathrm{Y}$
: Koefisien regresi variabel independen

: Motivasi Kualitas

: Motivasi Sosial

: Motivasi Ekonomi

: Biaya Pendidikan

: Lama Masa Studi

: Minat mahasiswa mengikuti Pendidikan Profesi Akuntansi 


\section{HASIL DAN PEMBAHASAN}

Analisis statistik deskriptif digunakan untuk memberikan informasi mengenai karakteristik variabel penelitian statistik deskriptif menjelaskan skala jawaban responden pada setiap variabel independen yang diukur dari nilai minimum, nilai maksimum, nilai tengah (mean) dan standar deviasi. Hasil lengkapnya dapat dilihat pada tabel berikut:

\section{Tabel 3. Hasil StatistikDeskriptif}

\begin{tabular}{lccccc}
\hline \multicolumn{1}{c}{ Variabel } & $\mathrm{N}$ & Minimum & Maximum & Mean & Std. Deviation \\
\hline Motivasi kualitas $\left(\mathrm{X}_{1}\right)$ & 60 & 15 & 30 & 23.42 & 3.850 \\
Motivasi sosial $\left(\mathrm{X}_{2}\right)$ & 60 & 15 & 25 & 19.73 & 3.091 \\
Motivasi ekonomi $\left(\mathrm{X}_{3}\right)$ & 60 & 15 & 30 & 23.28 & 3.858 \\
Biaya pendidikan $\left(\mathrm{X}_{4}\right)$ & 60 & 9 & 20 & 15.55 & 3.254 \\
Lama masa studi $\left(\mathrm{X}_{5}\right)$ & 60 & 15 & 30 & 23.27 & 3.940 \\
Minat Mahasiswa & 60 & 15 & 24 & 19.60 & 2.323 \\
Mengikuti PPAk $(\mathrm{Y})$ & & & & &
\end{tabular}

Sumber: Data Penelitian, 2019

Berdasarkan tabel 3 diatas dapat dijelaskan bahwa variabel motivasi kualitas memiliki nilai minimum 15 dan nilai maksimum 30. Hal ini menunjukkan nilai terendah dari variabel motivasi kualitas yaitu sebesar 15 dimiliki oleh variabel pengetahuan perpajakan dan keahlian dalam praktik audit. Sedangkan nilai tertinggi 30 dimiliki oleh variabel peningkatan pengetahuan organisasional dan lingkungan bisnis. Secara keseluruhan, nilai rata-rata variabel motivasi kualitas 23,42 dengan standar deviasi 3,850. Nilai rata-rata sebesar 23,42 menunjukkan bahwa responden pada wilayah pernyataan pada kuesioner cenderung setuju pada masing-masing item pernyataan, artinya range tinggi. Dikatakan setuju karena nilai rata-rata berada pada poin 4 (tinggi) yang dapat dilihat pada Lampiran 6 perhitungan range variabel independen dan dependen. Standar deviasi 3,850 berarti bahwa terdapat penyimpangan antara nilai variabel motivasi kualitas yang telah diteliti dengan nilai rata-rata 3,850.

Variabel motivasi sosial memiliki nilai minimum 15 dan nilai maksimum 25. Hal ini menunjukkan nilai terendah dari variabel motivasi kualitas yaitu sebesar 15 dimiliki oleh variabel bergaul secara baik dengan orang lain. Sedangkan nilai tertinggi 25 dimiliki oleh variabel mengikuti pendidikan profesi akuntansi agar mendapatkan pretise dari orang lain. Secara keseluruhan, nilai rata-rata variabel motivasi sosial 19,73 dengan standar deviasi 3,091. Nilai ratarata sebesar 19,73 menunjukkan bahwa responden pada wilayah pernyataan pada kuesioner cenderung kurang setuju pada masing-masing item pernyataan, artinya range sedang. Dikatakan kurang setuju karena nilai rata-rata berada pada poin 3 (sedang) yang dapat dilihat pada Lampiran 6 perhitungan range variabel independen dan dependen. Standar deviasi 3,091 berarti bahwa terdapat penyimpangan antara nilai variabel motivasi sosial yang telah diteliti dengan nilai rata-rata 3,091.

Variabel motivasi ekonomi memiliki nilai minimum 15 dan nilai maksimum 30. Hal ini menunjukkan nilai terendah dari variabel motivasi ekonomi yaitu sebesar 15 dimiliki oleh variabel pekerjaan yang memberikan gaji 
tambahan yang tinggi. Sedangkan nilai tertinggi 30 dimiliki oleh variabel mengikuti pendidikan profesi akuntansi dengan mendapatkan pekerjaan yang memberikan program dana pensiun. Secara keseluruhan, nilai rata-rata variabel motivasi ekonomi 23,28 dengan standar deviasi 3,858. Nilai rata-rata sebesar 23,28 menunjukkan bahwa responden pada wilayah pernyataan pada kuesioner cenderung setuju pada masing-masing item pernyataan, artinya range tinggi. Dikatakan setuju karena nilai rata-rata berada pada poin 4 (tinggi) yang dapatdilihat pada Lampiran 6 perhitungan range variabel independen dan dependen. Standar deviasi 3,858 berarti bahwa terdapat penyimpangan antara nilai variabel motivasi ekonomi yang telah diteliti dengan nilai rata-rata 3,858.

Variabel biaya pendidikan memiliki nilai minimum 9 dan nilai maksimum 20. Hal ini menunjukkan nilai terendah dari variabel biaya pendidikan yaitu sebesar 9 dimiliki oleh variabel biaya kuliah per semester yang terjangkau. Sedangkan nilai tertinggi 20 dimiliki oleh variabel membayar biaya kuliah pendidikan profesi akuntansi per semester untuk menjadi seorang akuntan yang professional . Secara keseluruhan, nilai rata-rata variabel biaya 15,55 dengan standar deviasi 3,254. Nilai rata-rata sebesar 15,55 menunjukkan bahwa responden pada wilayah pernyataan pada kuesioner cenderung sangat tidak setuju pada masing-masing item pernyataan, artinya range sanga trendah . Dikatakan sangat tidak setuju karena nilai rata-rata berada pada poin 1 (sangat rendah) yang dapat dilihat pada Lampiran 6 perhitungan range variabel independen dan dependen. Standar deviasi 3,254 berarti bahwa terdapat penyimpangan antara nilai variabel biaya pendidikan yang telah diteliti dengan nilai rata-rata 3,254.

Variabel lama masa studi memiliki nilai minimum 15 dan nilai maksimum 30. Hal ini menunjukkan nilai terendah dari variabel lama masa studi yaitu sebesar 15 dimiliki oleh variabel batas waktu selama menempuh pendidikan profesi akuntansi relatif singkat. Sedangkan nilai tertinggi 30 dimiliki oleh variabel rentang masa studi di pendidikan profesi akuntansi relatif terlalu panjang. Secara keseluruhan, nilai rata-rata variabel motivasi ekonomi 23,27 dengan standar deviasi 3,940. Nilai rata-rata sebesar 23,27 menunjukkan bahwa responden pada wilayah pernyataan pada kuesioner cenderung setuju pada masing-masing item pernyataan, artinya range tinggi. Dikatakan setuju karena nilai rata-rata berada pada poin 4 (tinggi) yang dapat dilihat pada Lampiran 6 perhitungan range variabel independen dan dependen. Standar deviasi 3,940 berarti bahwa terdapat penyimpangan antara nilai variabel motivasi ekonomi yang telah diteliti dengan nilai rata-rata 3,940.

Tabel 4. Hasil Uji Analisis Regresi Linear Berganda

\begin{tabular}{llllcc}
\hline \multicolumn{1}{c}{ Variabel } & \multicolumn{2}{l}{$\begin{array}{l}\text { Unstandardized } \\
\text { Coefficients } \\
\text { B }\end{array}$} & $\begin{array}{l}\text { Standardized Error } \\
\text { Coefficients } \\
\text { Beta }\end{array}$ & $\begin{array}{c}\mathrm{t} \\
\text { hitung }\end{array}$ & Sig. uji t \\
\hline (Constant) & 3,865 & 1,635 & & 2,364 & 0,022 \\
Motivasi kualitas $\left(\mathrm{X}_{1}\right)$ & 0,143 & 0,055 & 0,236 & 2,610 & 0,012 \\
Motivasi sosial $\left(\mathrm{X}_{2}\right)$ & 0,175 & 0,076 & 0,233 & 2,302 & 0,025 \\
Motivasi ekonomi $\left(\mathrm{X}_{3}\right)$ & 0,128 & 0,053 & 0,212 & 2,412 & 0,019 \\
Biaya pendidikan $\left(\mathrm{X}_{4}\right)$ & 0,166 & 0,066 & 0,233 & 2,520 & 0,015 \\
\hline
\end{tabular}

Bersambung... 
Lanjutan Tabel. 4

\begin{tabular}{lllll}
\hline Lama masa studi $\left(\mathrm{X}_{5}\right)$ & $0,145 \quad 0,059$ & 0,247 & 2,451 & 0,018 \\
Dependen Variabel & $:$ MinatMahasiswa & & & \\
R Square & $: 0,646$ & & & \\
Adjust $\left(\mathrm{R}^{2}\right)$ & $: 0,613$ & & & \\
F Statistik & $: 19,695$ & & \\
Signifikansi Uji F & $: 0,000$ & & & \\
\hline
\end{tabular}

Sumber: Data Penelitian, 2019

Berdasarkan hasil analisis regresi linear berganda seperti yang disajikan pada Tabel 4 maka dapat dibuat persamaan struktural sebagai berikut :

$$
Y=3,865+0,143 X_{1}+0,175 X_{2}+0,128 X_{3}+0,166 X_{4}+0,145 X_{5}
$$

Keterangan :

$\mathrm{Y}=$ Minat mahasiswa

$\mathrm{X}_{1}=$ Motivasi kualitas

$\mathrm{X}_{2}=$ Motivasi sosial

$\mathrm{X}_{3}=$ Motivasi ekonomi

$\mathrm{X}_{4}=$ Biaya pendidikan

$\mathrm{X}_{5}=$ Lama masa studi

Hasil analisis kelayakan model $\mathrm{F}$ dapat dilihat dari tabel 4 menunjukan bahwa $F$ hitung sebesar 19,695 dan nilai signifikansi uji $F$ yaitu sebesar 0,000 lebih kecil dari 0,05, hal ini berarti $\mathrm{H}_{0}$ di tolak dan $\mathrm{H}_{\mathrm{a}}$ di terima. Hasil ini memiliki makna bahwa variabel motivasi kualitas, motivasi sosial, motivasi ekonomi, biaya pendidikan dan lama masa studi dapat atau layak digunakan untuk memprediksi variabel minat mahasiswa.

Nilai $t$ hitung pada variabel motivasi kualitas sebesar 2,610 dan signifikansi sebesar 0,012. Dengan menggunakan batas signifikansi sebesar 0,05 maka nilai signifikansi tersebut lebih kecil dari 5 persen yang berarti $\mathrm{H}_{0}$ di tolak dan $\mathrm{H}_{\mathrm{a}}$ di terima. Hal ini menunjukan bahwa motivasi kualitas memiliki pengaruh positif pada minat mahasiswa mengikuti PPAk. Koefisien regresi variabel motivasi kualitas $\left(X_{1}\right)$ sebesar 0,143 , hal ini berarti bahwa apabila variabel motivasi kualitas $\left(X_{1}\right)$ mengalami peningkatan, maka akan meningkatkan minat mahasiswa mengikuti PPAk sebesar 0,143 dengan asumsi variabel bebas konstan.

Nilai t hitung pada variabel motivasi sosial sebesar 2,302 dan signifikan sebesar 0,025. Dengan menggunakan batas signifikansi sebesar 0,05 maka nilai signifikansi tersebut lebih kecildari 5 persen yang berarti $\mathrm{H}_{0}$ di tolak dan $\mathrm{H}_{\mathrm{a}}$ di terima. Hal ini menunjukan bahwa motivasi sosial memiliki pengaruh positif pada minat mahasiswa. Koefisien regresi variabel motivasi sosial $\left(\mathrm{X}_{2}\right)$ sebesar 0,175, hal ini berarti bahwa apabila variabel motivasi sosial $\left(X_{2}\right)$ mengalami peningkatan, maka akan meningkatkan minat mahasiswa sebesar 0,175 dengan asumsi variabel bebas konstan.

Nilai $t$ hitung pada variabel motivasi ekonomi sebesar 2,412 dan signifikan sebesar 0,019. Dengan menggunakan batas signifikansi sebesar 0,05 maka nilai signifikansi tersebut lebih kecil dari 5 persen yang berarti $\mathrm{H}_{0}$ di tolak dan $\mathrm{H}_{\mathrm{a}}$ di terima. Hal ini menunjukan bahwa motivasi ekonomi memiliki pengaruh positif pada minat mahasiswa. Koefisien regresi variabel motivasi ekonomi $\left(X_{3}\right)$ sebesar 0,128 , hal ini berarti bahwa apabila variabel motivasi 
ekonomi $\left(X_{3}\right)$ mengalami peningkatan, maka akan meningkatkan minat mahasiswa sebesar 0,128 dengan asumsi variabel bebas konstan.

Nilai $\mathrm{t}$ hitung pada variabel biaya pendidikan sebesar 2,520 dan signifikan sebesar 0,015. Dengan menggunakan batas signifikansi sebesar 0,05 maka nilai signifikansi tersebut lebih kecil dari 5 persen yang berarti $\mathrm{H}_{0}$ di tolak dan $\mathrm{H}_{\mathrm{a}}$ di terima. Hal ini menunjukan bahwa biaya pendidikan memiliki pengaruh positif pada minat mahasiswa. Koefisien regresi variabel biaya pendidikan $\left(\mathrm{X}_{4}\right)$ sebesar 0,166, hal ini berarti bahwa apabila variabel biaya pendidikan $\left(\mathrm{X}_{4}\right)$ mengalami peningkatan, maka akan meningkatkan minat mahasiswa sebesar 0,166 dengan asumsi variabel bebas konstan.

Nilai $t$ hitung pada variabel lama masa studi sebesar 2,451 dan signifikansi sebesar 0,018. Dengan menggunakan batas signifikansi sebesar 0,05 maka nilai signifikansi tersebut lebih kecil dari 5 persen yang berarti $\mathrm{H}_{0}$ di tolak dan $\mathrm{H}_{\mathrm{a}}$ di terima. Hal ini menunjukan bahwa lama masa studi memiliki pengaruh positif pada minat mahasiswa. Koefisien regresi variabel lama masa studi $\left(X_{5}\right)$ sebesar 0,145, hal ini berarti bahwa apabila variabel lama masa studi $\left(\mathrm{X}_{5}\right)$ mengalami peningkatan, maka akan meningkatkan minat mahasiswa sebesar 0,145 dengan asumsi variabel bebas konstan.

Koefisien determinasi $\left(R^{2}\right)$ bertujuan untuk menunjukkan seberapa jauh kemampuan variabel independen dalam menerangkan variasi variabel dependen. Nilai Adjust $\left(\mathrm{R}^{2}\right)$ adalah sebesar sebesar 0,613 hal ini berarti variasi variabel minat mahasiswa dapat dijelaskan oleh motivasi kualitas, motivasi sosial, motivasi ekonomi, biaya pendidikan dan lama masa studi sebesar 61,3 persen. Sedangkan sisanya sebesar 38,7 persen dipegaruhi oleh variabel-variabel lain diluar model penelitian.

Hasil analisis menunjukan bahwa motivasi kualitas berpengaruh positif terhadap minat mahasiswa mengikuti pendidikan profesi akuntansi. Hal ini memiliki makna bahwa semakin baik motivasi kualitas yang dimiliki maka akan meningkatkan minat mahasiswa mengikuti pendidikan profesi akuntansi di Universitas Udayana, begitu juga sebaliknya apabila motivasi kualitas yang dimiliki kurang baik maka akan menurunkan minat mahasiswa mengikuti pendidikan profesi akuntansi di Universitas Udayana. Artinya semakin berkualitas pendidikan profesi akuntansi maka akan meningkatkan minat mahasiswa mengikuti pendidikan profesi akuntansi, ini dikarenakan motivasi kualitas suatu dorongan yang timbul dalam diri seseorang untuk memiliki dan meningkatkan kualitas diri dan kemampuannya dalam bidang yang ditekuninya sehingga dapat melaksanakan tugas dengan baik dan benar Widyastuti \& Juliana (2004). Salah satu alasan seseorang bisa termotivasi dalam pengambilan keputusan adalah dalam meningkatkan kualitas seseorang dan prestasi (Tella, 2007). Dengan memiliki kualitas pendidikan yang baik maka akan memeberikan dorongan yang kuat pada minat mahasiswa.

Hal ini sesuai dengan hasil penelitian yang dilakukan oleh Aryani \& Erawati (2016) dan Dyastasari \& Yadnyana (2016) menunjukkan bahwa motivasi kualitas berpengaruh positif pada minat mahasiswa mengikuti Pendidikan Profesi Akuntansi.

Hasil analisis menunjukan bahwa motivasi sosial berpengaruh positif pada minat mahasiswa mengikuti pendidikan profesi akuntansi. Hal ini 
memiliki makna bahwa semakin baik motivasi sosial yang dimiliki maka akan meningkatkan minat mahasiswa mengikuti pendidikan profesi akuntansi di Universitas Udayana, begitu juga sebaliknya apabila motivasi sosial yang dimiliki kurang baik maka akan menurunkan minat mahasiswa mengikuti pendidikan profesi akuntansi di Universitas Udayana. Artinya semakin diakui gelar yang didapat setelah mengikuti pendidikan profesi akuntansi maka akan meningkatkan minat mahasiswa mengikuti profesi pendidikan akuntansi. Hal ini dikarenakan motivasi sosial adalah motivasi yang mendasari aktivitas yang dilakukan individu dalam reaksinya terhadap orang lain, jika ia dalam membuat pilihan memperhitungkan akibatnya bagi orang lain (Martameh, 2012). Motivasi sosial diartikan sebagai suatu dorongan seseorang untuk melakukan perbuatan dengan tujuan bernilai sosial, memperoleh pengakuan maupun penghargaan dari lingkungan dimana seseorang berada, disamping itu motivasi sosial secara psikologis mampu mengabaikan perandari jenis kelamin seseorangDyastasari \& Yadnyana (2016). Dengan mendapat sebutan akuntan yang didapat dari mengikuti pendidikan akuntansi, maka muncul kepuasan dalam diri seseorang karena kemampuan yang dimiliki atau prestasi yang diraih mendapat apresiasi oleh orang lain dan lingkungan sekitarnya.

Hal ini sesuai dengan hasil penelitian yang dilakukan oleh (Kusumo \& Ahyani (2015) dan Dyastasari \& Yadnyana (2016) menunjukan bahwa motivasi sosial berpengaruh positif pada minat mahasiswa mengikuti Pendidikan Profesi Akuntansi

Hasil analisis menunjukan bahwa motivasi ekonomi berpengaruh positif pada minat mahasiswa mengikuti pendidikan profesi akuntansi. Hal ini memiliki makna bahwa semakin baik motivasi ekonomi yang dimiliki maka akan meningkatkan minat mahasiswa mengikuti pendidikan profesi akuntansi di Universitas Udayana, begitu juga sebaliknya apabila motivasi ekonomi yang dimiliki kurang baik maka akan menurunkan minat mahasiswa mengikuti pendidikan profesi akuntansi di Universitas Udayana. Artinya semakin baik penghargaan ekonomi yang didapat setelah mengikuti profesi pendidikan akuntansi maka akan meningkatkan minat mahasiswa untuk mengikuti pendidikan profesi akuntansi. Hal ini di karenakan motivasi ekonomi adalah dorongan yang timbul dalam diri seseorang untuk meningkatkan kemampuan pribadinya dalam rangka untuk mencapai penghargaan finansial yang diinginkan (Widyastuti \& Juliana, 2004). Dengan adanya penghargaan ekonomi yang tinggi akan di dapat setelah mengikuti pendidikan profesi akuntansi maka akan meningkatkan minat mahasiwa mengikuti pendidikan profesi akutansi.

Hal ini sesuai dengan hasil penelitian yang dilakukan oleh Kusumastuti (2013) dan Kurniawan (2017) yang menyatakan bahwa motivasi ekonomi berpengaruh positif pada minat mahasiswa mengikuti Pendidikan Profesi Akuntansi

Hasil analisis menunjukan bahwa biaya pendidikan berpengaruh positif pada minat mahasiswa mengikuti pendidikan profesi akuntansi. Hal ini memiliki makna bahwa semakin sesuai biaya pendidikan maka akan meningkatkan minat mahasiswa mengikuti pendidikan profesi akuntansi di Universitas Udayana, begitu juga sebaliknya apabila biaya pendidikan tidak sesuai maka akan menurunkan minat mahasiswa mengikuti pendidikan profesi 
akuntansi di Universitas Udayana. Artinya semakin sesuai biaya untuk mengikuti pendidikan profesi akuntansi maka akan meningkatkan minat mahasiswa mengikuti pendidikan profesi akuntansi ini di karenakan biaya pendidikan merupakan keseluruhan pengorbanan finansial yang dikeluarkan oleh mahasiswa untuk keperluan selama menempuh pendidikan dari awal sampai berakhirnya pendidikan Aryani \& Erawati (2016). Dengan adanya biaya pendidikan yang sesuai dengan kualitas pendidikan pada pendidikan profesi akuntansi maka akan meningkatkan minat mahasiswa mengikuti Pedidikan Profesi Akutansi.

Hal ini sesuai dengan hasil penelitian yang dilakukan Kurniawan (2017) dan Sapitri \& Yaya (2015) menunjukkan biaya pendidikan berpengaruh positif pada minat mahasiswa mengikuti Pendidikan Profesi Akuntansi.

Hasil analisis menunjukan bahwa lama masa studi berpengaruh positif pada minat mahasiswa mengikuti pendidikan profesi akuntansi. Hal ini memiliki makna bahwa semakin sesuai lama masa studi maka akan meningkatkan minat mahasiswa mengikuti pendidikan profesi akuntansi di Universitas Udayana, begitu juga sebaliknya apabila lama masa studi tidak sesuai maka akan menurunkan minat mahasiswa mengikuti pendidikan profesi akuntansi di Universitas Udayana. Artinya semakin sesuai lama masa studi untuk mengikuti pendidikan profesi akuntansi maka akan meningkatkan minat mahasiswa mengikuti pendidikan profesi akuntansi. Ini di karenakan lama masa studi adalah proses yang harus dijalani oleh seorang mahasiswa untuk menempuh Pendidikan Profesi Akuntansi dan mendapat gelar akuntan ini merupakan hal yang perlu diperhatikan karena lamanya masa studi dapat menunda seseorang untuk bekerja. Oleh keinginan setelah melihat, mengamati, membandingkan dan mempertimbangkan dengan kebutuhan yang diinginkan. Dengan adanya lama masa studi yang sesuai maka akan meningkatkan minat mahasiswa mengikuti pendidikan profesi akutansi.

Hal ini sesuai dengan hasil penelitian yang dilakukan (Yuneriya et al. 2013) yang menyatakan masa studi berpengaruh positif terhadap minat mahasiswa mengikuti pendidikan profesi akuntansi. Hasil penelitian ini memberikan tambahan informasi mengenai bagaimana dampak motivasi kualitas, motivasi sosial, motivasi ekonomi, biaya pendidikan dan lama masa studi pada minat mahasiswa mengikuti Pendidikan Profesi Akuntansi. Hasil penelitian ini diharapkan dapat memberikan kontribusi positif bagi semua pihak khususnya mahasiswa akuntansi program S1 dalam mengikuti Pendidikan Profesi Akuntansi (PPAk). Adanya hasil penelitian ini juga dapat memberikan informasi mengenai faktor yang dapat menghambat minat mahasiswa mengikuti Pendidikan Profesi Akuntansi.

\section{SIMPULAN}

Motivasi kualitas berpengaruh positif pada minat mahasiswa mengikuti pendidikan profesi akuntansi di Universitas Udayana. Hal ini dapat diartikan bahwa semakin baik motivasi kualitas yang dimiliki maka akan meningkatkan minat mahasiswa mengikuti pendidikan profesi akuntansi di Universitas Udayana. Motivasi sosial berpengaruh positif pada minat mahasiswa mengikuti pendidikan profesi akuntansi di Universitas Udayana. Hal ini dapat diartikan 
bahwa semakin baik motivasi sosial yang dimiliki maka akan meningkatkan minat mahasiswa mengikuti pendidikan profesi akuntansi di Universitas Udayana. Motivasi ekonomi berpengaruh positif pada minat mahasiswa mengikuti pendidikan profesi akuntansi di Universitas Udayana. Hal ini dapat diartikan bahwa semakin baik motivasi ekonomi yang dimiliki maka akan meningkatkan minat mahasiswa mengikuti pendidikan profesi akuntansi di Universitas Udayana. Biaya pendidikan berpengaruh positif pada minat mahasiswa mengikuti pendidikan profesi akuntansi di Universitas Udayana. Hal ini dapat diartikan bahwa semakin sesuai biaya pendidikan maka akan meningkatkan minat mahasiswa mengikuti pendidikan profesi akuntansi di Universitas Udayana. Lama masa studi berpengaruh positif pada minat mahasiswa mengikuti pendidikan profesi akuntansi di Universitas Udayana. Hal ini dapat diartikan bahwa semakin sesuai lama masa studi maka akan meningkatkan minat mahasiswa mengikuti pendidikan profesi akuntansi di Universitas Udayana.

Dalam upaya meningkatkan motivasi kualitas mahasiswa untuk mengikuti pendidikan profesi akuntansi di Universitas Udayana dapat dilakukan dengan meningkatkan pengetahuan perpajakan dan keahlian dalam praktik audit.Dalam upaya meningkatkan motivasi sosial mahasiswa untuk mengikuti pendidikan profesi akuntansi di Universitas Udayana dapat dilakukan dengan bergaul secara baik dengan orang lain. Dalam upaya meningkatkan motivasi ekonomi mahasiswa untuk mengikuti pendidikan profesi akuntansi di Universitas Udayana dapat dilakukan dengan mendapatkan pekerjaan yang memberikan gaji tambahan yang tinggi. Dalam upaya menyesuaikan biaya pendidikan mahasiswa untuk mengikuti pendidikan profesi akuntansi di Universitas Udayana dapat dilakukan dengan cara biaya kuliah per semester yang terjangkau. Dalam upaya menyesuaikan lama masa studi mahasiswa untuk mengikuti pendidikan profesi akuntansi di Universitas Udayana dapat dilakukan dengan batas waktu selama menempuh PPAk relatif singkat.

Bagi peneliti selanjutnya, agar dapat meneliti dan mengkaji lebih dalam faktor-faktor lain yang tidak diteliti dalam penelitian ini yang dapat mempengaruhi minat mahasiswa mengikuti pendidikan profesi akuntansi selain motivasi kualitas, motivasi sosial, motivasi ekonomi, biaya pendidikan dan lama masa studi. Agar nantinya dapat mengetahui tindakan apa yang harus dilakukan dalam upaya meningkatkan mahasiswa mengikuti pendidikan profesi akuntansi di Universitas Udayana.

\section{REFERENSI}

Andoko, C. Y., \& Sukhemi. (2015). Pengaruh Motivasi terhadap Minat Mahasiswa Akuntansi untuk Mengikuti Pendidikan Profesi Akuntansi (PPAK). Akmenika, 12(2), 652-659. Retrieved from http://upy.ac.id/ojs/index.php/akm/article/ view/121

Aryani, N. P. D., \& Erawati, N. M. (2016). Pengaruh Motivasi Kualitas, Karir, Ekonomi, dan Biaya Pendidikan pada Minat Mahasiswa Mengikuti PPAk. E-Jurnal Akuntansi Universitas Udayana, 16(1), 362-387. Retrieved from https://ojs.unud.ac.id/index.php/Akuntansi/article/view/17469/14314

Ayuningtyas, N., \& Prihatini, F. N. (2012). Faktor-Faktor Yang Mempengaruhi 
Minat Mahasiswa Akuntansi Untuk Mengikuti Pendidikan Profesi Akuntansi (PPAK). Juraksi, 1(1), 85-98. Retrieved from http://journal.usm.ac.id/jurnal/juraksi/ 171/detail/

Diah, F. (2012). Pengaruh Motivasi terhadap Minat Mahasiswa Akuntansi untuk mengikuti Pendidikan Profesi Akuntansi (PPAk). Accruals, 3(1), 1-12. Retrieved from https://ojs.stiesa.ac.id/index.php/accruals/issue/view/3

Dyastasari, N. P. S., \& Yadnyana, I. K. (2016). Pengaruh Motivasi pada Minat Mahasiswa Non Akuntansi untuk Mengikuti PPAk. E-Jurnal Akuntansi Universitas Udayana, 16(1), 333-361. Retrieved from https://ojs.unud.ac.id/index.php/Akuntansi/article/view/17380/14313

Indrawati, N. (2009). Motivasi dan Minat Mahasiswa Untuk Mengikuti Pendidikan Profesi Akuntansi (PPAk). Pekbis, Jurnal, 1(2), 124-130. Retrieved from https://media.neliti.com/media/publications/8936-ID-motivasi-danminat-mahasiswa-untuk-mengikuti-pendidikan-profesi-akuntansi-ppak.pdf

Kurniawan, D. H. (2017). Analisis Pengaruh Motivasi Karir, Motivasi Ekonomi, Pengalaman Kerja dan Biaya Pendidikan pada Minat Mengikuti PPAk. Universitas Muhammadiyah Surakarta. Retrieved from http://eprints.ums.ac.id/ 51945/12/Naskah Publikasi.pdf

Kusumasturi, R., \& Indarto, W. (2013). Pengaruh Motivasi dan Pengetahuan UU No.5 Tahun 2011 Tentang Akuntan Publik Terhadap Minat Mahasiswa Akuntansi Mengikuti PPAk (PPAk). Nominal, 2(2), 1-30. https://doi.org/ https://doi.org/10.21831/nominal.v2i2.1662

Kusumo, D., \& Ahyani, F. (2015). Pengaruh Motivasi Terhadap Minat Mahasiswa Akuntansi untuk Mengikuti PPAk (PPAk) (Studi Empiris pada Mahasiswa Universitas Muhammadiyah Surakarta dan Universitas Sebelas Maret. Universitas Muhammadiyah Surakarta. Retrieved from https://core.ac.uk/download/pdf/148607114.pdf

Lubis, A. I. (2014). Akuntansi Keperilakuan (2nd ed.). Jakarta: Salemba Empat.

Martameh, M. S. (2012). Motivasi Sosial. Yogyakarta: Universitas Gajah Mada.

Nazir, M. (2008). Metode Penelitian. Jakarta: Ghalia Indonesia.

Nurhayati, U. (2012). Pengaruh Motivasi Terhadap Minat Mahasiswa Akuntansi untuk Mengikuti PPAk (PPAk). Jurnal Mediasi, 4(1), 59-67. Retrieved from http://digilib.unimed.ac.id/417/1/Fulltext.pdf

Paisey, C., \& Paisey, N. J. (2006). Cutting to the core? A reflection upon recent education policy debates within the Institute of Chartered Accountants in England and Wales. The British Accounting Review, 38(1), 31-61. https://doi.org/https://doi.org/10.1016/j.bar.2005.08.002

Perkasa, Y. B., \& Sudarma, M. (2014). Pengaruh Motivasi Terhadap Minat Mahasiswa untuk Mengikuti Pendidikan Profesi Akuntansi (Studi Empiris pada Mahasiswa Akuntansi Universitas Brawijaya). Jurnal Ilmiah Mahasiswa, 2(2), 1-12. Retrieved from https://jimfeb.ub.ac.id/index.php/jimfeb/article/view/1179

Pita, S., \& Sasongko, N. (2016). Pengaruh Motivasi, Biaya Pendidikan, dan Lama Pendidikan Terhadap Minat Mahasiswa Akuntansi Untuk Mengikuti Pendidikan Profesi Akuntansi (PPAk). Universitas Muhammadiyah Surakarta. Retrieved from http:/ / eprints.ums.ac.id/41436/

Puspitarini, Di., \& Kusumawati, F. (2011). Faktor-Faktor Yang Mempengaruhi 
Minat Mahasiswa Mengikuti Pendidikan Profesi Akuntansi (PPAk). Jurnal Infestasi, 7(1), 1-12. Retrieved from http://journal.trunojoyo.ac.id/infestasi/ article/view/491

Rahardian, I. (2008). Pengaruh Motivasi Terhadap Minat Mahasiswa untuk Mengikuti PPAk. Universitas Katolik Soegijapranata Semarang. Retrieved from http:// repository.unika.ac.id/2482/

Salistera, S. Y., \& Kusumastuti, R. (2013). Pengaruh Lingkungan Kerja terhadap Produktivitas Kerja Karyawan pada Production Plant PT Indocement Tunggal Prakarsa TBK Citeurep. Fakultas Ilmu Sosial Dan Ilmu Politik, Universitas Indonesia, 1(1), 1-18. Retrieved from http://lib.ui.ac.id/naskahringkas/2015-09/S46515-sinta yulis salistera

Sapitri, Z., \& Yaya, R. (2015). Faktor-Faktor yang Berpengaruh Terhadap Minat Mahasiswa untuk Mengikuti Pendidikan Profesi Akuntansi (PPAk). Journal of Accounting and Investment, 16(1), 46-61. Retrieved from http://journal.umy.ac.id/index.php/ai/article/view/1347/1391

Tella, A. (2007). The Impact of Motivation on Student's Academic Achievement and Learning Outcomes in Mathematics among Secondary School Students in Nigeria. Eurasia Journal of Mathematics, Science $\mathcal{E}$ Technology Education, 3(2), 149-156. https:// doi.org/https:/ / doi.org/10.12973/ejmste/75390

Vesperalis, A. A. A. D., \& Muliartha, K. R. (2017). Pengaruh Motivasi pada Minat Sarjana Akuntansi Universitas Udayana untuk Mengikuti PPAk. E-Jurnal Akuntansi Universitas Udayana, 19(2), 1691-1718. Retrieved from https://simdos.unud.ac.id/uploads/file_penelitian_1_dir/7ca3a7986f9be56 a75a8929c0e77f0d1.pdf

Widyasari, Y. (2010). Persepsi Mahasiswa Akuntansi Mengenai Faktor-Faktor Yang Membedakan Pemilihan Karir. Universitas Diponegoro.

Widyastuti, S., \& Juliana. (2004). Pengaruh Motivasi terhadap Minat Mahasiswa Akuntansi untuk Mengikuti PPAk (PPAk). In Simposium Nasional Akuntansi VII. Denpasar.

Wijaya, B. K. (2010). Cara Cerdas Pilih Jurusan Demi Profesi Impian. Yogyakarta: Jogja Great Publisher.

Yuneriya, N. E., Sarwono, A. E., \& Kristanto, D. (2013). Pengaruh Motivasi, Persepsi Dan Lama Pendidikan Terhadap Minat Mahasiswa Untuk Mengikuti Pendidikan Profesi Akuntansi. Jurnal Ekonomi Dan Kewirasuahaan, 13(1), 69-77. Retrieved from http://ejurnal.unisri.ac.id/index.php/Ekonomi/article/download/547/47 9 